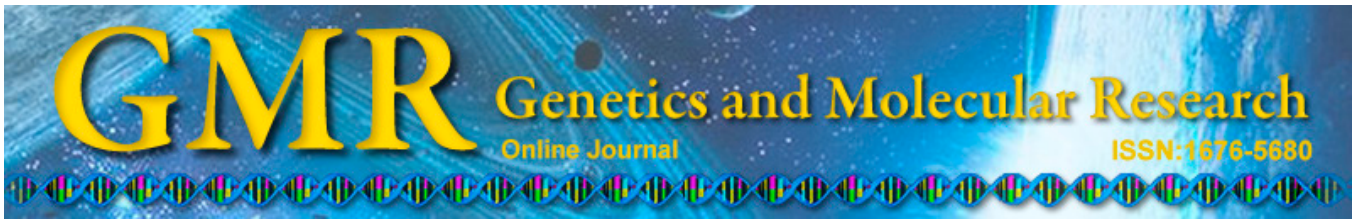

\title{
Screening of molecular markers linked to dwarf trait in crape myrtle by bulked segregant analysis
}

\author{
Y.J. Ye ${ }^{1 *}$, Y. Liu ${ }^{1 *}$, M. Cai ${ }^{1}$, D. He ${ }^{2}$, J.S. Shen ${ }^{1}$, Y.Q. Ju${ }^{1}$, X.M. Bian ${ }^{1}$, \\ H.T. Pan ${ }^{1}$ and Q.X. Zhang ${ }^{1}$ \\ ${ }^{1}$ Beijing Key Laboratory of Ornamental Plants Germplasm Innovation \& \\ Molecular Breeding, \\ National Engineering Research Center for Floriculture and College of \\ Landscape Architecture, Beijing Forestry University, Beijing, China \\ ${ }^{2}$ Department of Ornamental Horticulture, College of Horticulture, \\ Henan Agricultural University, Zhengzhou, China \\ *These authors contributed equally to this study. \\ Corresponding author: H.T. Pan \\ E-mail: htpan@bjfu.edu.cn
}

Genet. Mol. Res. 14 (2): 4369-4380 (2015)

Received May 27, 2014

Accepted September 25, 2014

Published April 30, 2015

DOI http://dx.doi.org/10.4238/2015.April.30.10

\begin{abstract}
Plant height is one of the most important traits of plant architecture as it modulates both economic and ornamental values. Crape myrtle (Lagerstroemia indica L.) is a popular ornamental woody plant because of its long-lasting mid-summer bloom, rich colors, and diversified plant architecture. These traits also make it an ideal model of woody species for genetic analysis of many ornamental traits. To understand the inheritance of plant height and screen for genes modulating plant height in Lagerstroemia, segregation of the plant height trait was analyzed using the $\mathrm{F}_{1}$ population of $L$. fauriei (standard) x L. indica 'Pocomoke' (dwarf) with 96 seedlings, while dwarf genes were screened using the bulked segregant analysis method, combined with 28 amplified fragment length polymorphism primers and 41 simple sequence repeat primers. The results showed that the dwarf trait of crape myrtle was controlled by a major gene and modified by minor genes. An
\end{abstract}


amplified fragment length polymorphism marker, M53E39-92, which was $23.33 \mathrm{cM}$ from the loci controlling the dwarf trait, was screened. These results provide basic information for marker-assisted selection in Lagerstromia and cloning of dwarf genes in future studies.

Key words: Amplified fragment length polymorphism; Bulked segregant analysis; Lagerstroemia; Plant architecture; Simple sequence repeat

\section{INTRODUCTION}

Plant height is one of the most important plant architecture traits and is closely related to production, quality, and ornamental value (Petersen and Krost, 2013). Studies of plant architecture have focused on the biology of this trait, beginning with the introduction of lodging-resistant semidwarf wheat and rice mutants that led to the Green Revolution in the 1960s (Peng et al., 1999). The genetic mechanism of plant architecture in crops has been improved (Gallavotti et al., 2010), and batch of genes modulating plant height have been successfully cloned (Dardick et al., 2013).

For woody plants, studies of plant architecture mainly focus on fruit trees. Different genes determining important traits such as columnar growth habit (Tian et al., 2005), and the rootstock dwarf gene $D w 1$ in apple have been mapped, some of which are currently being used effectively in breeding programs (Rusholme Pilcher et al., 2008). Furthermore, to identify genes involved in columnar architecture, high-throughput RNA-Seq technology was used in a segregating population of 'Fuji' x 'Telamon' (Zhang et al., 2012). However, few studies on plant architecture of ornamental plants have been reported. Several transgenic chrysanthemum lines were produced and used to express the Arabidopsis thaliana gai gene (gibberellic acid insensitive) under its own promoter, which exhibited a range of dwarf phenotypes (Petty et al., 2003). Studies examining the inheritance of creeping habit and molecular markers linked to this habit were carried out to provide a basis for molecular marker-assisted selection breeding programs, and to clone creeping habit-related genes from the ground-cover Chrysanthemum (Zhao et al., 2009).

Lagerstroemia (crape myrtle) belongs to the Lythraceae family, including at least 50 species native to southeastern Asia (Byers, 1997). China was the first country to cultivate crape myrtle, which took place approximately 1800 years ago (Zhang, 1991). Some species in this genus are of enormous significance in mild-climate habitats because of their long-lasting summer bloom, rich colors, and diverse patterns, and thus are widely used in gardens (Pooler, 2003). Additionally, crape myrtle is regarded as an indispensable source of income for companies and retail nursery growers. Recently, increased attention has been given to select dwarf crape myrtle mutants, and breeding programs to develop dwarf cultivars have been pursued in America, Italy, and Japan (Pooler, 2007). Because of the limited knowledge of inheritance of plant habit, a long period of time is required to breed dwarf cultivars. Significant progress has been made in the breeding of cultivars with diverse flower size and color (Whitcomb, 1985; Pounders et al., 2007), high resistance to powdery mildew (Pettis et al., 2004), and polyploidy cultivars (Ye et al., 2010; Wang et al., 2012) in crape myrtle. However, few studies have examined the inheritance of plant architecture in crape myrtle.

Compared with other woody plants, there are some advantages to investigate plant architecture using crape myrtle: 1) There are diverse patterns of plant types in Lagerstroemia, including arbors $(>3 \mathrm{~m})$, bushes, and mini shrubs $(0.3-0.6 \mathrm{~m}) ; 2)$ large hybrid populations can be obtained easily by crossing for its abundant blooms in summer; and 3) crape myrtle seedlings 
grow rapidly and bloom in a short period of time. Thus, crape myrtle is an ideal model of woody plants for genetic analysis of many ornamental traits, including plant architecture characteristics.

Various agronomic traits, such as fertility, plant height, and resistance, are controlled by major genes and are considered qualitative traits. Traditionally, gene mapping is based on genetic linkage maps, which are restricted by mapping population, marker density, and resource consumption. Compared to genetic linkage maps, bulked segregant analysis (BSA) is an effective and efficient method of mapping target genes (Michelmore et al., 1991). With the rapid development of molecular biology techniques, DNA markers combined with BSA have been extensively used for qualitative traits analysis of many crops, including Actinidia chinensis (Xu et al., 2010), Malus domestica (Tian et al., 2004), and Pyrus (Wang et al., 2011). Among all DNA markers, amplified fragment length polymorphism (AFLP) is effective when little knowledge is available regarding the genome sequence (Waugh et al., 1997). Additionally, simple sequence repeats (SSRs) are abundant, co-dominant, and highly polymorphic in Lagerstroemia species and cultivars (Cai et al., 2011; Wang et al., 2011; He et al., 2012), and can be used as molecular markers for gene mapping in Lagerstroemia.

To determine the genetic mechanism behind the dwarf trait and screen for genes modulating plant height of Lagerstroemia, the segregation of plant height trait was analyzed using an $\mathrm{F}_{1}$ population of Lagerstroemia fauriei (standard) x Lagerstroemia indica 'Pocomoke' (dwarf). Dwarf genes were screened using the BSA method combined with AFLP and SSRs. Our results provide a foundation for breeding of new crape myrtle cultivars using markerassisted selection and for studying the inheritance of the plant height trait of Lagerstroemia.

\section{MATERIAL AND METHODS}

\section{Plant materials}

The $\mathrm{F}_{1}$ population in our study was obtained from a cross of Lagerstroemia fauriei (female) x L. indica 'Pocomoke' (male) (Figure 1). Parents were selected for their contrasting plant architecture traits. The female parent was an arbor $(>3 \mathrm{~m})$ with wide leaves and long internodes, and the male parent was a dwarf shrub $(0.3-0.6 \mathrm{~m})$ with small leaves and short internodes (Pooler and Dix, 1999; Liu et al., 2013).

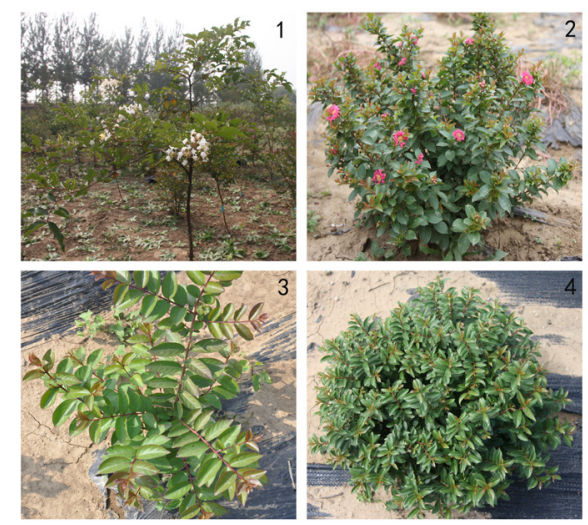

Figure 1. Standard type (3) and dwarf type (4) of 1-year-old seedlings in $F_{1}$ population of Lagerstroemia fauriei (female) (1) x L. indica 'Pocomoke' (male) (2). 
In November 2011, mature hybrid seeds were harvested. At the beginning of 2012, seeds were sowed in a greenhouse, and then 142 seedlings were transplanted in June 2012 at the experimental field in ornamental plant germplasm and breeding nursery of China National Engineering Research Center for Floriculture in Beijing. To study the height trait, no training was used to maintain the original plant shapes. Additionally, regular irrigation and pest control were used throughout this study.

\section{Phenotypic measurements and statistical analysis}

Remarkable character separation of plant height was observed in the $\mathrm{F}_{1}$ population after the first year of growth. At that time, we randomly selected 96 individuals to measure plant height and constructed the frequency distribution histogram using Spass17.0 and Excel (Zhao et al., 2009). Using the mean height of 1-year-old standard seedlings as a reference, dwarf seedlings were distinguished based on half height of the standard seedlings (Xu et al., 2010). Mendelian segregation was tested at a 1\% signification level between standard type and dwarf type individuals by performing a chi-square goodness-of-fit test.

\section{DNA extraction}

Genomic DNA was extracted from fresh young leaves using the FastDNA kit (Tiangen Biotech, Beijing, China) following the manufacturer protocol. DNA quality and concentration were measured by $1 \%$ agarose gel electrophoresis containing Gel Red at $0.1 \mu \mathrm{g} / \mathrm{mL} 1 \mathrm{X}$ TAE buffer, with bands visualized under UV light (Zhu et al., 2011).

\section{AFLP protocol}

AFLP was performed according to the method described by He et al. (2014), including restriction enzyme digestion, a pre-amplification reaction, and selective amplification. In this study, a total of 384 AFLP primer combinations were used. Primers and adapters were synthesized by Beijing Ruibo Biotech Co., Ltd. (Beijing, China). We digested $100 \mathrm{ng}$ DNA for $14 \mathrm{~h}$ at $37^{\circ} \mathrm{C}$ in a mixture of $5 \mathrm{pM} \mathrm{EcoRI} \mathrm{adapter,} 50 \mathrm{pM} \mathrm{MseI} \mathrm{adapter,} 5 \mathrm{U}$ EcoRI, $5 \mathrm{U}$ MseI, $1 \mathrm{X} \mathrm{T}_{4}$ ligase buffer, and $4 \mathrm{U} \mathrm{T}_{4}$ DNA ligase (New England Biolabs, Ipswich, MA, USA). Pre-amplification reactions were performed in a $20-\mu \mathrm{L}$ volume containing 3 $\mu \mathrm{L}$ enzyme-digested products, $10 \mu \mathrm{L} 2 \mathrm{X}$ Taq PCR Master Mix (Biomiga, San Diego, CA, USA), $0.6 \mu \mathrm{L}$ of each forward and reverse primer, and $5.8 \mu \mathrm{L} \mathrm{ddH}_{2} \mathrm{O}$. The polymerase chain reaction (PCR) procedure was as follows: $94^{\circ} \mathrm{C}$ for $5 \mathrm{~min}$; followed by 30 cycles of $94^{\circ} \mathrm{C}$ for $35 \mathrm{~s}, 56^{\circ} \mathrm{C}$ for $35 \mathrm{~s}$, and $72^{\circ} \mathrm{C}$ for $1 \mathrm{~min}$; final extension step at $72^{\circ} \mathrm{C}$ for $10 \mathrm{~min}$. The pre-amplification products were diluted 1:20 with $\mathrm{ddH}_{2} \mathrm{O}$, and $3 \mu \mathrm{L}$ was used for selective amplification. The PCR procedure was performed in a $20-\mu \mathrm{L}$ volume containing $3 \mu \mathrm{L}$ preamplification products, $10 \mu \mathrm{L} 2 \mathrm{X} \mathrm{Taq}$ PCR Master Mix, $0.6 \mu \mathrm{L}$ of each forward and reverse primer, and $5.8 \mu \mathrm{L} \mathrm{ddH_{2 }} \mathrm{O}$. Among the primers, M19, M51, M52, M24, M25, and M53 were labeled with a fluorescent tag. The selective amplification procedure was as follows: $94^{\circ} \mathrm{C}$ for $5 \mathrm{~min}$; followed by 13 cycles of $94^{\circ} \mathrm{C}$ for $35 \mathrm{~s}, 56^{\circ} \mathrm{C}$ for $30 \mathrm{~s}$, and $72^{\circ} \mathrm{C}$ for $1 \mathrm{~min} ; 30$ cycles of $94^{\circ} \mathrm{C}$ for $35 \mathrm{~s}, 56^{\circ} \mathrm{C}$ for $35 \mathrm{~s}$, and $72^{\circ} \mathrm{C}$ for $1 \mathrm{~min}$; final extension step at $72^{\circ} \mathrm{C}$ for $10 \mathrm{~min}$. 


\section{SSR protocol}

A total of 41 SSR primers demonstrated to be highly polymorphic in crape myrtle were tested (Wang et al., 2011; He et al., 2012). All primers were synthesized by Sangon Biotech (Shanghai) Co., Ltd. (Shanghai, China) (Table 1). The forward primer labeled with a fluorescent tag (Sangon) matched the reverse primer. SSR reactions were performed in a 10$\mu \mathrm{L}$ volume containing $100 \mathrm{ng}$ DNA, $5 \mu \mathrm{L} 2 \mathrm{X}$ Taq PCR Master Mix, $0.5 \mu \mathrm{L}$ of each forward and reverse primer, and $3 \mu \mathrm{L} \mathrm{ddH_{2 }} \mathrm{O}$. The PCR procedure was as follows: $94^{\circ} \mathrm{C}$ for $5 \mathrm{~min}$; followed by 30 cycles of $94^{\circ} \mathrm{C}$ for $30 \mathrm{~s}$, appropriate anneal temperature $\left(45^{\circ}-60^{\circ} \mathrm{C}\right)$ for $30 \mathrm{~s}$, and $72^{\circ} \mathrm{C}$ for $1 \mathrm{~min}$; final extension was performed at $72^{\circ} \mathrm{C}$ for $5 \mathrm{~min}$.

\section{Pool construction}

Pool construction was conducted according to the method of Michelmore et al. (1991) with some modifications. Individuals in the $\mathrm{F}_{1}$ population were divided into standard and dwarf types based on plant height when the plants stopped growing in winter. We randomly selected 8 plants from standard and dwarf type, and then mixed their DNA in the same volume separately. Different primer combinations were tested to screen for polymorphisms. If a polymorphic band was screened in 1 pool but not screened in another, a polymorphic marker was identified in the corresponding locus.

\section{Data analysis}

PCR products of AFLP and SSR were verified using GeneMarker Version 1.71 (SoftGenetics, State College, PA, USA) according to the method described by Jakubowski et al. (2011). AFLP data were scored as ' 1 ' or ' 0 ' in the form of Excel, while SSR data were exported as fragment sizes. The primer combinations yielding candidate markers were subsequently applied to each individual from the $\mathrm{F}_{1}$ population (Cervera et al., 1996). Genetic distance in centimorgans (cM) were calculated using the Kosambi mapping function (Kosambi, 1944). Furthermore, the validity of screened polymorphic marker was verified by replicate tests and testing individual plants in the $\mathrm{F}_{1}$ population.

\section{RESULTS}

\section{Segregation analysis of plant height in $F_{1}$ population}

Ninety-six individuals from the $\mathrm{F}_{1}$ population were selected randomly for measurement of plant height; the frequency distribution histogram was constructed using spass 17.0 and Excel. The distribution of plant height of 1-year-old $\mathrm{F}_{1}$ seedlings showed continuous variation and was mainly concentrated on the ranges of 1015 and $3040 \mathrm{~cm}$ (Figure 2). As shown in Figure 2, the number of individuals taller than $30 \mathrm{~cm}$ and shorter than $15 \mathrm{~cm}$ was surveyed. Statistical analysis showed that there were 33 standard individuals and 36 dwarf individuals. Chi-square test showed that the Mendelian segregation was in the theoretical ratio of 1:1 (Table 2). Combined with the parent phenotypes, the dwarf trait in crape myrtle was likely controlled by a major gene and modified by minor genes. 
Table 1. Nucleotide sequences of 41 SSR primers.

\begin{tabular}{|c|c|c|c|c|}
\hline Locus & Primer sequence $\left(5^{\prime}-3^{\prime}\right)$ & Repeat & $\operatorname{Tm}\left({ }^{\circ} \mathrm{C}\right)$ & Allele size (bp) \\
\hline$\overline{\text { SSR1 }}$ & $\begin{array}{l}\text { F: <FAM>AGAGAAAGAGAGGAGCGGGAGT } \\
\text { R: ACCTTCTTCCCCAATTCAATCC }\end{array}$ & $(\mathrm{GT})_{6} \mathrm{GC}(\mathrm{GT})_{6}$ & 55 & 213 \\
\hline SSR2 & $\begin{array}{l}\text { F: }<\text { FAM>ACGTTTAGCACACCGGTACTGT } \\
\text { R: GGAAGCACATCACTATGGCAAG }\end{array}$ & $(\mathrm{GT})_{7}$ & 55 & 181 \\
\hline SSR3 & $\begin{array}{l}\text { F: <FAM>GGTGGAGATGCTAACAAGCAAG } \\
\text { R: GGATTTTTGCTGTAGGGTGATT }\end{array}$ & $(\mathrm{TG})_{16}$ & 55 & 161 \\
\hline SSR4 & $\begin{array}{l}\text { F: }<\text { FAM }>\text { CCCTCATACCTTCTTTATCAAGTCA } \\
\text { R: ATCCCCACAAAATCTCTCCTTC }\end{array}$ & $(\mathrm{AC})_{13}$ & 55 & 215 \\
\hline SSR5 & $\begin{array}{l}\text { F: <FAM }>\text { TGGGATCGATGCTATTAATGTTG } \\
\text { R: TACACCAATTCACACCTCCACTC }\end{array}$ & $(\mathrm{GT})_{8}$ & 55 & 207 \\
\hline SSR6 & $\begin{array}{l}\text { F: <FAM >ACATGGCTCCCATCACACAG } \\
\text { R: CAGGGGATTCTTGTTTTGCTTT }\end{array}$ & $(\mathrm{AC})_{6}$ & 55 & 160 \\
\hline SSR7 & $\begin{array}{l}\text { F: }<\text { ROX }>\text { CTCTCAAATGACCCTCTT } \\
\text { R: TTGAGTAATAACAAGTCCC }\end{array}$ & $(\mathrm{AAAG})_{5}$ & 48 & 255 \\
\hline SSR8 & $\begin{array}{l}\text { F: }<\text { HEX }>\text { GAGTTCATGCAGTTAGGT } \\
\text { R: ATATCGGATTTATCTTCC }\end{array}$ & $(\mathrm{AAG})_{6}$ & 48 & 130 \\
\hline SSR9 & $\begin{array}{l}\text { F: }<\text { ROX }>\text { GGAAGAGGGATTGGAACC } \\
\text { R: TCTCACTGAAAGAAACTA }\end{array}$ & $(\mathrm{GA})_{5} \mathrm{G}(\mathrm{GGA})_{4}$ & 48 & 134 \\
\hline SSR 10 & $\begin{array}{l}\text { F: }<\text { HEX >ACGGTAGATAAGGTGAGC } \\
\text { R: GGTTCGTATCGTCGTAG }\end{array}$ & $(\mathrm{CT})_{9} \mathrm{~T}(\mathrm{CTGT}) \mathrm{GT}(\mathrm{CTGT})_{4}$ & 52 & 166 \\
\hline SSR11 & $\begin{array}{l}\text { F: }<\text { HEX>TACTGGGTATCCGTTTCT } \\
\text { R: ACAGGTGCATTTACTTCC }\end{array}$ & $(\mathrm{CT})_{6} \mathrm{CC}(\mathrm{CT})_{12}$ & 50 & 317 \\
\hline SSR12 & $\begin{array}{l}\text { F: }<\text { FAM }>\text { TTCTGACCCAGCAGTAAA } \\
\text { R: CGTATCTCATCTGTAGCGTA }\end{array}$ & $(\mathrm{AGGT})_{4}$ & 50 & 138 \\
\hline SSR13 & $\begin{array}{l}\text { F: }<\text { HEX }>\text { GGGAATTTGGGATATGGA } \\
\text { R: TAAAGAAACGACCGAGCC }\end{array}$ & $(\mathrm{AAAG})_{5}$ & 52 & 179 \\
\hline SSR14 & $\begin{array}{l}\text { F: }<\text { HEX }>\text { GTCACAGGTTACCGAATC } \\
\text { R: ATGTAAATGGTGAGGAGG }\end{array}$ & $(\mathrm{AATC})_{5}$ & 50 & 253 \\
\hline SSR15 & $\begin{array}{l}\text { F: }<\text { ROX }>\text { TTCTTGTCTTGGGTATCGC } \\
\text { R: GAGCCAGTATTGTCTTCACG }\end{array}$ & $(\mathrm{CCTT})_{7}$ & 50 & 228 \\
\hline SSR16 & $\begin{array}{l}\text { F: }<\text { HEX }>\text { TTCTTCCACTTCCTCCTT } \\
\text { R: CAGCCCACATTAACTTTT }\end{array}$ & $(\mathrm{AG})_{12}$ & 50 & 204 \\
\hline SSR17 & $\begin{array}{l}\text { F: <FAM>AAAGACGCAGAAGGATGG } \\
\text { R: CGATTAGTTTCAGCTCGT }\end{array}$ & $(\mathrm{AG})_{20}$ & 50 & 420 \\
\hline SSR 18 & $\begin{array}{l}\text { F: <FAM }>\text { GGACCAGATTGTAAATGC } \\
\text { R: CTGCTCCTAATATCAGTGTC }\end{array}$ & $(\mathrm{CT})_{15}$ & 50 & 289 \\
\hline SSR 19 & $\begin{array}{l}\text { F: }<\text { HEX>TAGTCCATTCATGTCAAG } \\
\text { R: GGATTCACCAAACTACTT }\end{array}$ & $(\mathrm{AG})_{14}$ & 52 & 246 \\
\hline SSR20 & $\begin{array}{l}\text { F: <FAM }>\text { TTTGGTGGTAGTGGGAGT } \\
\text { R: GTGTCTGCATGGCTGTAA }\end{array}$ & $(\mathrm{CTGT})_{6}$ & 54 & 305 \\
\hline SSR21 & $\begin{array}{l}\text { F: }<\text { ROX }>\text { CCTAACAAGAAAGGAACAG } \\
\text { R: TTTCAGGACATCAGCACC }\end{array}$ & $(\mathrm{AG})_{11}$ & 60 & 144 \\
\hline SSR22 & $\begin{array}{l}\text { F: }<\text { HEX }>\text { CCTCCTCCTGCCACTCCTCT } \\
\text { R: CCCGTCGTCTCCTCAGTTCTC }\end{array}$ & $(\mathrm{AAG})_{4} \mathrm{AG}(\mathrm{AAG})_{2}$ & 54 & 194 \\
\hline SSR23 & $\begin{array}{l}\text { F: <FAM }>\text { CAACAGTAAAATTGGAGC } \\
\text { R: AGTAGTGATTCGGGTGGA }\end{array}$ & $(\mathrm{CTTT})_{7}$ & 55 & 144 \\
\hline SSR24 & $\begin{array}{l}\text { F: }<\text { HEX>ATCAATGTCCACAACAACTTGCC } \\
\text { R: GGTTTGGTCGATTTGGTTCAGTTA }\end{array}$ & $(\mathrm{AAG})_{7}$ & 55 & 158 \\
\hline SSR25 & $\begin{array}{l}\text { F: <FAM>TACACTCCCTCCCATTCAGATTGT } \\
\text { R: GCTGCCTGAATCAGTGAAGAGAGT }\end{array}$ & $(\mathrm{AGA})_{7}$ & 55 & 97 \\
\hline SSR26 & $\begin{array}{l}\text { F: }<\text { HEX >ACGTATCAACCGAATGACCACTTT } \\
\text { R: GAATTCAAAGCTCAAGTGGGGAC }\end{array}$ & $(\mathrm{TTC})_{10}$ & 55 & 137 \\
\hline SSR27 & $\begin{array}{l}\text { F: }<\text { HEX }>\text { GTCTCACTCTCTCAACTCAAGGGC } \\
\text { R: TGAGAAAGAATTTTTCCTGAACCG }\end{array}$ & $(\mathrm{TCT})_{6}$ & 55 & 137 \\
\hline SSR28 & $\begin{array}{l}\text { F: }<\text { HEX }>\text { ATGTACACCCGAAACCCTTTAGGT } \\
\text { R: TCCATGTCTTGTCACAGCCTCTAC }\end{array}$ & $(\mathrm{TCT})_{7}$ & 55 & 131 \\
\hline SSR29 & $\begin{array}{l}\text { F: }<\text { FAM }>\text { TGTCACTTCTGCAAATAT } \\
\text { R: AACTACTGCCATCATACT }\end{array}$ & $(\mathrm{TC})_{7}$ & 50 & 229 \\
\hline SSR 30 & $\begin{array}{l}\text { F: <FAM }>\text { GTGTTGGGAGTCAGATGG } \\
\text { R: ACAGCCGTTCGACATTAA }\end{array}$ & $(\mathrm{AC})_{6}$ & 48 & 191 \\
\hline SSR31 & $\begin{array}{l}\text { F: <FAM>AGCTGGCTGGTTGGGAGT } \\
\text { R: AAGGGTTTTACAAGAAATGGAC }\end{array}$ & $(\mathrm{ACTC})_{3}$ & 54 & 189 \\
\hline
\end{tabular}

Continued on next page 


\begin{tabular}{|c|c|c|c|c|}
\hline Locus & Primer sequence $\left(5^{\prime}-3^{\prime}\right)$ & Repeat & $\operatorname{Tm}\left({ }^{\circ} \mathrm{C}\right)$ & Allele size (bp) \\
\hline SSR32 & $\begin{array}{l}\text { F: }<\text { HEX }>\text { AAGCCCGACTCAGAAACT } \\
\text { R: ACTATGACTCGGCCTTCC }\end{array}$ & $\left(\right.$ TATG $_{9}$ & 50 & 129 \\
\hline SSR33 & $\begin{array}{l}\text { F: }<\text { HEX }>\text { CGGGACCGACAAAATACT } \\
\text { R: AGGGAAGATGTTGGAAGG }\end{array}$ & $(\mathrm{TCTG})_{5}$ & 50 & 163 \\
\hline SSR34 & $\begin{array}{l}\text { F: <FAM }>\text { AATGAAGGTTCGGGTGC, } \\
\text { R: TCTGGCTTGAGGGTTTG }\end{array}$ & $(\mathrm{AG})_{5}$ & 54 & 322 \\
\hline SSR35 & $\begin{array}{l}\text { F: }<\text { FAM }>\text { GGAATCATCGACTGGGTAA } \\
\text { R: GCTCCTATGGCAGAACG }\end{array}$ & $(\mathrm{TGA})_{3}$ & 54 & 172 \\
\hline SSR36 & $\begin{array}{l}\text { F: }<\text { FAM }>\text { GATGGGTTTGGCTCTGC } \\
\text { R: GTCCTCCTCACTTGTTTCC }\end{array}$ & $(\mathrm{AG})_{17}$ & 54 & 348 \\
\hline SSR37 & $\begin{array}{l}\text { F: < HEX > TCAAGAGTGGCAGCATC } \\
\text { R: GGAACGGCTCTGATTGT }\end{array}$ & $(\mathrm{AGA})_{4}$ & 52 & 128 \\
\hline SSR38 & $\begin{array}{l}\text { F: }<\text { FAM }>\text { TTCTTTCCCATTGTTATTCG } \\
\text { R: CGTCGTCGGTGAACCTCT }\end{array}$ & $(\mathrm{CATA})_{4} \mathrm{CATT}(\mathrm{CATA})_{4}$ & 50 & 144 \\
\hline SSR39 & $\begin{array}{l}\text { F: <FAM }>\text { CCCAAGTTCAACAAATCTCC } \\
\text { R: ATCGTTTCCTGGCGTCT }\end{array}$ & $(\mathrm{GAA})_{6} \mathrm{GAG}(\mathrm{GAA})_{3}$ & 56 & 279 \\
\hline SSR40 & $\begin{array}{l}\text { F: }<\text { HEX }>\text { GGGCAGAACCTGACTTA } \\
\text { R: CTCCAACGGCTCAACTA }\end{array}$ & $(\mathrm{ATG})_{6}$ & 48 & 164 \\
\hline SSR41 & $\begin{array}{l}\text { F: }<\text { FAM }>\text { GCGTCAGTCAACCCTAA } \\
\text { R: ACAGCCGTTCGACATTAA }\end{array}$ & $(\mathrm{AG})_{21}$ & 50 & 475 \\
\hline
\end{tabular}

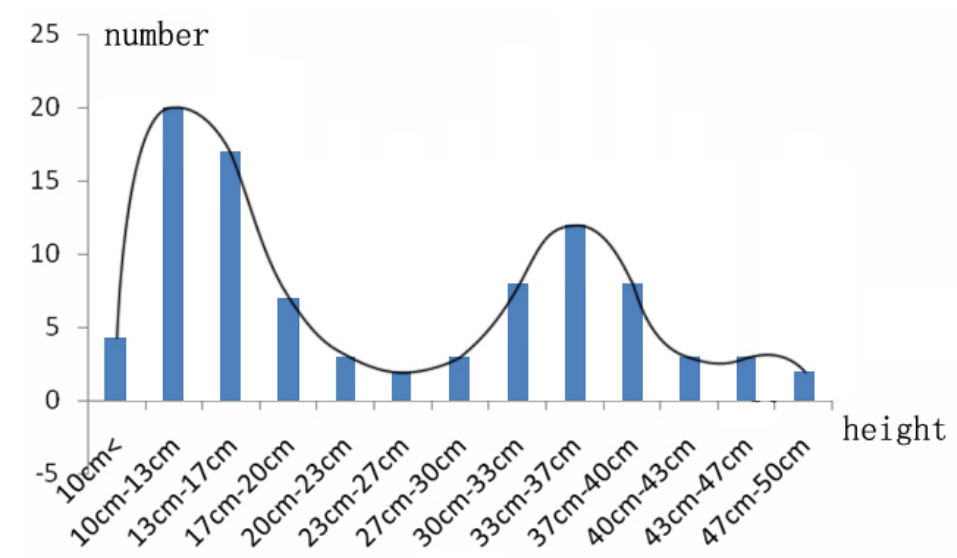

Figure 2. Distribution of plant height trait of 1-year-old seedlings in $F_{1}$ population of Lagerstroemia fauriei (female) (1) x L. indica 'Pocomoke' (male).

Table 2. Segregation of different plant height in $\mathrm{F}_{1}$ population of Lagerstroemia fauriei $\mathrm{x}$ L. indica 'Pocomoke'.

\begin{tabular}{|c|c|c|c|c|c|c|}
\hline \multirow[t]{2}{*}{ Progeny } & \multirow[t]{2}{*}{ No. of plants } & \multicolumn{2}{|c|}{ No. of individuals of different plant type } & \multirow[t]{2}{*}{ Theoretical ratio } & \multirow[t]{2}{*}{$\chi^{2}$} & \multirow[t]{2}{*}{$P$} \\
\hline & & Standard type & Dwarf type & & & \\
\hline $\mathrm{F}_{1}$ & 96 & 33 & 36 & $1: 1$ & 0.083 & 0.01 \\
\hline
\end{tabular}

\section{Polymorphisms revealed by molecular markers}

Among the 384 AFLP primer combinations, 28 pairs showing polymorphisms were selected, including 12 sequences for the $\mathrm{E}_{+3}$ primer and 6 sequences for the $\mathrm{M}_{+3}$ primer (Table 3). In AFLP analysis, the fragment size of PCR products ranged from 50-467 bp. A total of 192 polymorphic loci were screened, of which 25 were amplified by M24E36 (Table 4). The results revealed a 
specific fragment at $92 \mathrm{bp}$ amplified by M53E39-92, which was screened in both the male parent and dwarf type pool, but not in the female parent and standard type pool (Figure 3). Additionally, 27 SSR primers were polymorphic and 72 polymorphic loci were amplified in the subject materials. However, we did not screen any specific fragment that was different in relative pools.

\begin{tabular}{|c|c|c|c|}
\hline Primer No. & Primer sequences $\left(5^{\prime}-3^{\prime}\right)$ & Primer No. & Primer sequences $\left(5^{\prime}-3^{\prime}\right)$ \\
\hline$\overline{E 31}$ & GACTGCGTACCAATTCAAA & E41 & GACTGCGTACCAATTCAGG \\
\hline E32 & GACTGCGTACCAATTCAAC & E42 & GACTGCGTACCAATTCAGT \\
\hline E33 & GACTGCGTACCAATTCAAG & E43 & GACTGCGTACCAATTCATA \\
\hline E34 & GACTGCGTACCAATTCAAT & M19 & GATGAGTCCTGAGTAAGA \\
\hline E36 & GACTGCGTACCAATTCACC & M24 & GATGAGTCCTGAGTAATC \\
\hline E37 & GACTGCGTACCAATTCACG & M25 & GATGAGTCCTGAGTAATG \\
\hline E38 & GACTGCGTACCAATTCACT & M51 & GATGAGTCCTGAGTAACCA \\
\hline E39 & GACTGCGTACCAATTCAGA & M52 & GATGAGTCCTGAGTAACCC \\
\hline $\mathrm{E} 40$ & GACTGCGTACCAATTCAGC & M53 & GATGAGTCCTGAGTAACCG \\
\hline
\end{tabular}

Table 4. Number of AFLP amplification loci amplified by 28 different primer combinations.

\begin{tabular}{lccccc}
\hline Primer combination & Polymorphic fragment & Size range (bp) & Primer combination & Polymorphic fragment & Size range (bp) \\
\hline M19E33 & 5 & $55-289$ & M51E33 & 8 & 56 \\
M19E32 & 3 & $57-153$ & M51E36 & 316 \\
M19E37 & 2 & $57-87$ & M51E37 & 3 & $56-86$ \\
M24E33 & 22 & $51-416$ & M51E39 & 2 & $56-188$ \\
M24E36 & 25 & $53-228$ & M51E40 & 4 & $56-85$ \\
M24E37 & 12 & $52-215$ & M51E41 & 2 & $55-85$ \\
M24E38 & 22 & $56-300$ & M52E31 & 2 & $57-86$ \\
M24E39 & 14 & $50-169$ & M52E32 & 3 & $57-87$ \\
M24E42 & 7 & $51-339$ & M52E33 & 7 & $56-85$ \\
M24E43 & 13 & $152-175$ & M52E36 & 1 & $56-174$ \\
M25E37 & 1 & $63-85$ & M53E33 & 3 & $56-316$ \\
M25E40 & 3 & 90 & M53E41 & 19 & $54-182$ \\
M25E42 & 1 & $90-239$ & & $50-489$ \\
M25E43 & 2 & &
\end{tabular}
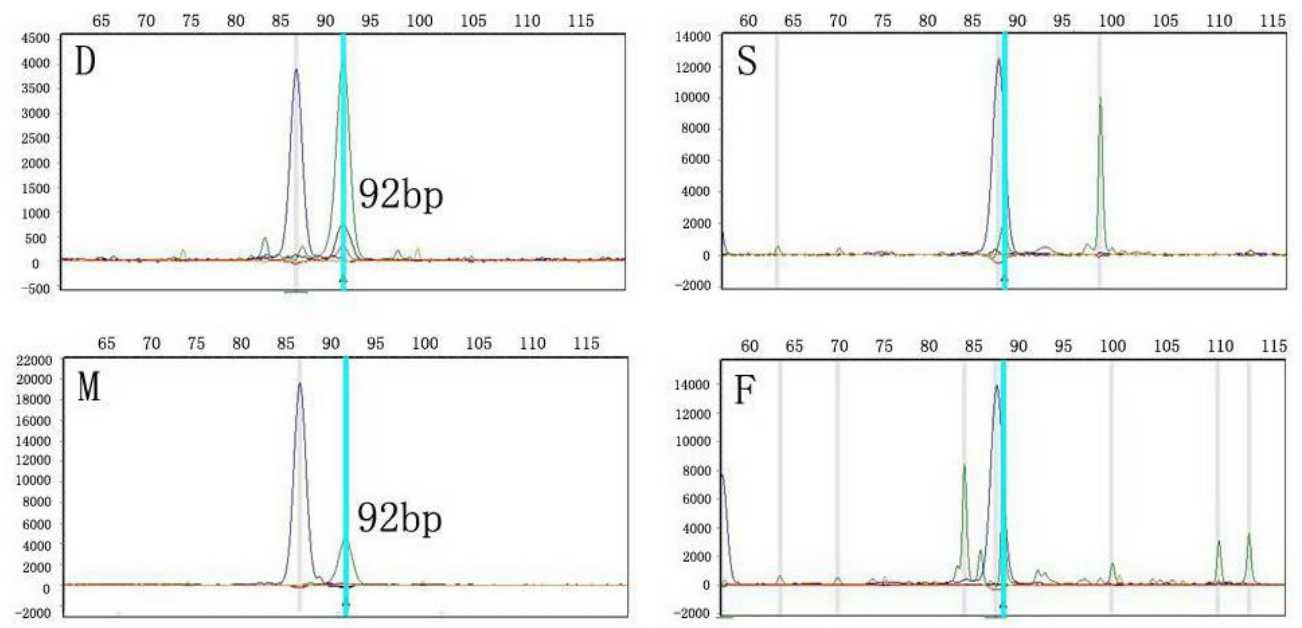

Figure 3. Amplification in pools and parents for primer M53E39 on the automated fluorescent-labeled system. D. Dwarf pool; M. male parent; S. standard pool; F. female parent. 


\section{Linkage analysis}

The specific AFLP marker M53E39-92 was found to be linked to the dwarf gene in crape myrtle. According to phenotypic measurements and statistical analysis, 33 standard individuals and 36 dwarf individuals in the $F_{1}$ population were selected randomly to verify the linkage of the AFLP marker. Sixteen recombination individuals were detected, occurring $23.33 \mathrm{cM}$ from dwarf genes.

\section{DISCUSSION}

Dwarf crape myrtles are becoming increasingly popular and widely used worldwide for various reasons, including being used as potted plants (Guidry and Einert, 1975) and bedding plants. However, the inheritance of this anomalous habit remains unclear (Pooler, 2007). We found that the dwarf trait of crape myrtle is likely controlled by a major gene and modified by minor genes. The $\mathrm{F}_{1}$ population, containing 96 individuals obtained from a cross of $L$. fauriei (female) x L. indica 'Pocomoke' (male), were observed in our study. Approximate discrete characters with respect to plant height was isolated in the $\mathrm{F}_{1}$ population. The distribution of plant height in the $\mathrm{F}_{1}$ population showed continuous variation. The chi-square test showed that both standard and dwarf plants were in the Mendelian ratio of 1:1. Combined with the results of other woody plants, the dwarf trait of crape myrtle was most likely controlled by a major gene (Xu et al., 2010). As an important ornamental character in crape myrtle, whether the dwarf trait is controlled by regulators or structure genes must be confirmed in future studies.

Based on our genetic analysis, BSA is a rapid and effective method for identifying markers linked to dwarf genes (Tian et al., 2004). BSA was first applied in linkage analysis of discrete traits in the $\mathrm{F}_{2}$ population (Michelmore et al., 1991), and also widely used to screen target traits in $\mathrm{F}_{1}$ populations (Zhao et al., 2009; Wang et al., 2011). The underlying principle of BSA is the grouping of informative individuals together so that a particular genomic region can be studied against a randomized genetic background of unlinked loci. In the present study, 8 individuals were selected randomly each from standard and dwarf type so that the insignificant signals derived from background discrepancies could be eliminated at the extreme, because the most appropriate number of individuals applied to construct gene bulks was 510 to avoid false-positives (Goivannoni et al., 1991). Moreover, L. fauriei (standard) and L. indica 'Pocomoke' (dwarf) showed large differences in plant height, indicating that the parents tested are highly polymorphic in the target region. The $\mathrm{F}_{1}$ individuals showed significant differences in plant height, internode length, and leaf size.

Twenty-eight AFLP primers from 384 primer combinations were examined to identify polymorphisms in this study. A total of 192 polymorphic loci were screened, of which 25 were amplified by M24E36. Of all primer combinations, the mean length of the amplified polymorphic site was 6.86. AFLP is an effective marker-based PCR technique characterized by dominant, is highly polymorphic, and requires little sequence information for the target species and template DNA. The prominent advantages of the AFLP technique compared to other PCRbased marker technologies are the reproducibility and number of screened markers (Powell et al., 1996). Until now, the AFLP technique combined with BSA have been widely employed for gene mapping studies (Aranda et al., 2014). For a dominant AFLP marker, the probability of an unlinked locus being polymorphic between 2 pools of 10 individuals was calculated to be 2 x $10^{-6}$ (Michelmore et al., 1991). In addition, 41 SSR primers known to be high polymorphic 
in crape myrtle were analyzed. However, specific markers linked to dwarf characters were not screened. SSR markers are preferred to other markers because SSR sequences generally show a high level of similarity across different species, genera, and families (Yang et al., 2014). Thus far, the number of SSR markers used in Lagerstroemia studies was less than 200, indicating that a very large gap remains compared with other species. Although SSR markers are generally regarded to be valuable for gene mapping, the lack of sufficient SSR markers still cannot evenly cover the entire genome, including the target region in crape myrtle.

Data analysis showed that a 92-bp fragment was screened in both the male parent and dwarf pool, but not in the female parent and standard pool. Finally, a molecular marker was identified and linked to the dwarf gene in crape myrtle. Replicating and testing the validity of this marker in the $\mathrm{F}_{1}$ population, the distance between the molecular marker and dwarf gene was found to be $23.33 \mathrm{cM}$. According to Michelmore et al. (1991), all polymorphic loci assayed within $15 \mathrm{cM}$ of the target locus can be identified. Loci are detected with decreasing frequency as genetic distance increases. Therefore, with a genetic distance of $23.33 \mathrm{cM}$ from dwarf genes, uncertainties regarding this Lagerstromia species may not be revealed by the specific marker. In the future, the inheritance of dwarf trait must be verified in the $\mathrm{F}_{2}$ or $\mathrm{BC}_{1}$ populations. Additionally, the number of molecular markers is a key factor that influenced the results in this study. To achieve an ideal effect in marker-assisted selection of the dwarf character, we will develop additional molecular markers to enhance the coverage area of $\mathrm{La}$ gerstromia species.

In conclusion, 96 seedlings in an $\mathrm{F}_{1}$ population were employed to screen molecular markers linked to the dwarf trait of crape myrtle using BSA combined with the AFLP and SSR technologies. An AFLP marker M53E39-92 linked to the dwarf gene was detected which was $23.33 \mathrm{cM}$ from the loci controlling the dwarf trait. This study revealed that BSA is a valuable method for identifying important traits in crape myrtle and the first to map dwarf genes in this species. Our results provide basic information for marker-assisted selection and cloning of the dwarf gene to improve crape myrtle breeding programs.

\section{ACKNOWLEDGMENTS}

Research supported by the 12th Five Years Key Programs for Science and Technology Development of China (\#2013BAD01B07) and the Special Fund for Beijing Common Construction Project (2013).

\section{REFERENCES}

Aranda L, Porch TG, Bassett MJ, Lara L, et al. (2014). Genetics and mapping of the Cl gene for circumlineated pattern in common bean using AFLP-based bulk segregant analysis and SNP-based bidirectional selective genotyping. J. Am. Soc. Hort. Sci. 139: 213-218.

Byers MD (1997). Crapemyrtle: A grower's thoughts. Owl Bay Publishers, Auburn.

Cai M, Pan HT, Wang XF, He D, et al. (2011). Development of novel microsatellites in Lagerstroemia indica and DNA fingerprinting in Chinese Lagerstroemia cultivars. Sci. Hortic. 131: 88-94.

Cervera MT, Gusmão J, Steenackers M, Peleman J, et al. (1996). Identification of AFLP molecular markers for resistance against Melampsora larici-populina in Populus. Theor. Appl. Genet. 93: 733-737.

Dardick C, Callahan A, Horn R, Ruiz KB, et al. (2013). PpeTAC1 promotes the horizontal growth of branches in peach trees and is a member of a functionally conserved gene family found in diverse plants species. Plant J. 75: 618-630.

Gallavotti A, Long JA, Stanfield S, Yang X, et al. (2010). The control of axillary meristem fate in the maize ramose 
pathway. Development 137: 2849-2856.

Goivannoni IL, Wing RA, Ganaland MW and Tanksley SD (1991). Isolation of molecular markers from specific chromosomal intervals using DNA pools from existing mapping populations. Nucleic Acid Res. 19: 6553-6558.

Guidry RK and Einert AE (1975). Potted dwarf crape myrtles: a promising new floriculture crop. Florists' Rev. 157: 30.

He D, Liu Y, Cai M, Pan HT, et al. (2012). Genetic diversity of Lagerstroemia (Lythraceae) species assessed by simple sequence repeat markers. Genet. Mol. Res. 11: 3522-3533.

He D, Liu Y, Cai M, Pan HT, et al. (2014). The first genetic linkage map of crape myrtle (Lagerstroemia) based on amplification fragment length polymorphisms and simple sequence repeats markers. Plant Breeding 133: 138-144.

Jakubowski AR, Casler MD and Jackson RD (2011). Has selection for improved agronomic traits made reed canarygrass invasive? PLoS One 6: e25757.

Kosambi DD (1944). The estimation of map distance from recombination values. Ann. Eugen. 12: 172-175.

Liu Y, Cai M, He D, Pan HT, et al. (2013). Construction of $\mathrm{F}_{1}$ segregation population for genetic linkage maps in Lagerstroemia. J. Northeast Forest. Univ. 41: 72-75.

Michelmore RW, Paran I and Kesseli RV (1991). Identification of markers linked to disease-resistance genes by bulked segregant analysis: a rapid method to detect markers in specific genomic regions by using segregating populations. Proc. Natl. Acad. Sci. U. S. A. 88: 9828-9832.

Peng J, Richards DE, Hartley NM, Murphy GP, et al. (1999). 'Green revolution' genes encode mutant gibberellin response modulators. Nature 400: 256-261.

Petersen R and Krost C (2013). Tracing a key player in the regulation of plant architecture the columnar growth habit of apple trees (Malus x domestica). Planta 238: 1-22.

Pettis GV, Boyd DW Braman SK and Pounders C (2004). Potential resistance of crape myrtle cultivars to flea beetle (Coleoptera: Chrysomelidae) and Japanese beetle (Coleoptera: Scarabaeidae) damage. J. Econ. Entomol. 97: 981-992.

Petty LM, Harberd NP, Carré IA, Thomas B, et al. (2003). Expression of the Arabidopsis gai gene under its own promoter causes a reduction in plant height in chrysanthemum by attenuation of the gibberellin response. Plant Sci. 164: 175-182.

Pooler MR (2003). Molecular genetic diversity among 12 clones of Lagerstroemia fauriei revealed by AFLP and RAPD markers. Hortscience 38: 256-259.

Pooler MR (2007). Chapter 15: Crapemyrtle. In: Flower Breeding and Genetics. Springer Publishing, New York, 439-457.

Pooler MR and Dix RL (1999). 'Chickasaw', 'Kiowa', and 'Pocomoke' Lagerstroemia. Hortscience 34: 361-363.

Pounders C, Rinehart T and Edwards N (2007). An analysis of combining ability for height, leaf out, bloom date, and flower color for crapemyrtle. Hortscience 42: 1496-1499.

Powell W, Morgante M, Andre C, Hanafey M, et al. (1996). The comparison of RFLP, RAPD, AFLP and SSR (microsatellite) markers for germplasm analysis. Mol. Breed. 2: 225-238.

Rusholme Pilcher RL, Celton JM and Gardiner SE (2008). Genetic markers linked to the dwarfing trait of apple rootstock 'Malling 9'. J. Am. Soc. Hort. Sci. 133: 100-106.

Tian YK, Wang CH, Dai HY and Zhang JS (2004). Screening of a RAPD marker tightly linked to Co gene in apple and the SCAR marker conversion. Acta Genet. Sin. 31: 919-925.

Tian YK, Wang CH, Zhang JS, James C, et al. (2005). Mapping Co, a gene controlling the columnar phenotype of apple, with molecular markers. Euphytica 145: 181-188.

Wang CH, Tian YK. Buck EJ, Gardiner SE, et al. (2011). Genetic mapping of PcDw determining pear dwarf trait. J. Am. Soc. Hort. Sci. 136: 48-53.

Wang XJ, Wang XF, Pan HT, Zhang QX, et al. (2012). In vitro chromosome doubling and tetraploid identification in Lagerstroemia indica. J. Food Agric. Environ. 10: 1364-1367.

Wang XW, Wadl PA, Pounders C, Trigiano RN, et al. (2011). Evaluation of genetic diversity and pedigree within crape myrtle cultivars using simple sequence repeat markers. J. Am. Soc. Hort. Sci. 136: 116-128.

Waugh R, Bonar N, Baird E, Thomas B, et al. (1997). Homology of AFLP products in three mapping populations of barley. Mol. Gen. Genet. 255: 311-321.

Whitcomb CE (1985). 'Centennial Spirit' crapemyrtle. Hortscience 20: 1144-1145.

Xu XB, Jiang CY, Liao J, Gu QQ, et al. (2010). Screening of EST-SSR marker linked to dwarf character in Actinidia chinensis planch. Acta Hort. Sin. 4: 553-558.

Yang XQ, Li Y, Zhang WW, He HL, et al. (2014). Fine mapping of the uniform immature fruit color gene $u$ in cucumber (Cucumis sativus L.). Euphytica 196: 341-348.

Ye YM, Tong J, Shi XP, Yuan W, et al. (2010). Morphological and cytological studies of diploid and colchicine-induced tetraploid lines of crape myrtle (Lagerstroemia indica L.). Sci. Hort. 124: 95-101.

Zhang QX (1991). Studies on cultivars of crape-myrtle (Lagerstroemia indica) and their uses in urban greening. J. Beijing Forest. Univ. 4: 59-68.

Zhang YG, Zhu J and Dai HY (2012). Characterization of transcriptional differences between columnar and standard apple 
trees using RNA-Seq. Plant Mol. Biol. Rep. 30: 957-965.

Zhao JY, Chen FD, Teng NJ and Chen SM (2009). Genetic analysis and RAPD marker of creeping habits in ground-cover Chrysanthemum. Sci. Agric. Sin. 42: 734-741.

Zhu RR, Gao YK, Xu LJ and Zhang QX (2011). Genetic diversity of Aquilegia (Ranunculaceae) species and cultivars assessed by AFLPs. Genet. Mol. Res. 10: 817-827. 